\title{
VIBROACOUSTIC HAZARD IN THE ENVIRONMENT
}

\section{WIBROAKUSTYCZNE ZAGROŻENIA ŚRODOWISKA}

https://doi.org/10.54215/NOISECONTROL2019_Cempel_Pleban

\section{Czesław CEMPEL, Dariusz PLEBAN}

Central Institute for Labour Protection - National Research Institute

Department of Vibroacoustic Hazards

ul. Czerniakowska 16, 00-701 Warsaw, Poland

\section{STRESZCZENIE}

Jednym z procesów fizycznych w naturze, środowisku pracy i życia człowieka są zjawiska akustyczne polegające na propagacji ruchu oscylacyjnego (wibracyjnego) w otoczeniu: gazowym (np. powietrze), ciekłym (np. woda), stałym ( $n$. grunt, materiaty konstrukcyjne). W gospodarce i technice niezamierzona generacja zjawisk akustycznych przybiera nieraz znaczne poziomy, na granicy bólu dla słuchu (120-130 dBA), lub innego typu szkodliwego oddziaływania, czyli zagrożenia zdrowia czy nawet życia. W pracy przedstawiono $\mathrm{W}$ skrótowej formie współczesne myślenie o zagrożeniach wibroakustycznych w środowisku naturalnym oraz w środowisku pracy i życia człowieka.

\section{AKUSTYKA I WIBROAKUSTYKA (WA)}

Jednym $\mathrm{z}$ procesów fizycznych $\mathrm{w}$ naturze, środowisku pracy i życia człowieka są zjawiska akustyczne polegające na propagacji ruchu oscylacyjnego (wibracyjnego) W otoczeniu: gazowym (np. powietrze), ciekłym (np. woda), stałym (np. grunt, materiały konstrukcyjne). W środowisku naturalnym są one sygnałami życia flory, fauny i człowieka, a także zmian atmosferycznych i zmian górotworu czy nawet gruntu. Cywilizacja ${ }^{1}$, którą stworzył człowiek w ciągu ostatnich kilku tysięcy lat oparta jest na przekształcaniu energii,

\footnotetext{
${ }^{1}$ W skrócie; Cywilizacja - sposób (technologia) zaspokajania potrzeb zbiorowych i jednostkowych, (np. czy podróżuję na koniu, czy tez ICE); Kultura - sposób rozumienia siebie i swego otoczenia, patrz np. [Cempel 2008].
} 
szczególnie do celów transportu, produkcji, itp.. Zaś efektywność każdego takiego przekształcenia jest znacznie mniejsza od 100\% i każdorazowo oprócz innych niechcianych efektów (ciepło, tarcie, itp.) niesie ze sobą współ generowane procesy drganiowe i akustyczne, często o bardzo wysokich poziomach. Jeśli przyjmiemy roboczą definicję, że hałas to każdy niepożądany dźwięk, to można by powiedzieć, że nasza cywilizacja jest hałaso-twórcza i w miarę rozwoju socjotechnicznego musimy sobie z tym sami radzić.

Całość procesów akustycznych dobrze jest podzielić na kilka mniejszych zakresów, a to z uwagi na ich specyfikę, występowanie i zastosowania. Najwcześniej każdy z nas uświadamia sobie dźwięki słyszalne o zakresie częstotliwości średnio; $20 \mathrm{~Hz}$ do $20 \mathrm{kHz}$. Poniżej zaś leży pasmo poddźwiękowe, infradźwiękowe o częstotliwościach średnio; $1 \mathrm{~Hz}$ do $20 \mathrm{~Hz}$, często odczuwane w uszach jako dudnienie, a przy dużych amplitudach przez całe ciało człowieka, zwłaszcza poszczególne narządy.

Częstotliwości wyższe w akustyce to ultradźwięki, dla nas niesłyszalne, ale używane przez zwierzęta w powietrzu (nietoperze) a zwłaszcza w wodzie do celów echolokacji (delfinywalenie). Dźwięki nisko częstotliwościowe łatwo są transformowane na drgania gruntu, ścian, konstrukcji wsporczych maszyn, itp. i odwrotnie, drgania takie generują dźwięk, dlatego też noszą one specjalna nazwę wibracje mechaniczne z zakresu $1 \mathrm{~Hz}$ do $100 \mathrm{~Hz}$. Generalnie efektywność generacji dźwięku nie jest wysoka, rzędu kilku procent, w wodzie nieco wyższa, a kierunkowość takich źródeł zależy od częstości. Dla częstotliwości niskich źródło dźwięku jest wszech kierunkowe, natomiast dla wysokich rzędu kilo Hertzów coraz bardziej zaznacza się kierunkowość aż do wąskiej wiązki dla ultradźwięków. To stąd ultradźwięki w przyrodzie używane są do celów echolokacji czynnej jak i biernej więcej patrz [Engel 2001, 2003], [Cempel 1978, 1989].

Jak można się domyślić z powyższego percepcja zjawisk dźwiękowych w przyrodzie jest różna, u człowieka jest ona nieliniowa i szeroka, zarówno co do amplitudy ciśnienia akustycznego jak i co do częstotliwości, stąd też w powszechnym obiegu jest skala logarytmiczna decybelowa $(\boldsymbol{d} \boldsymbol{B})$. Jak wiadomo ciśnienie, również akustyczne, mierzy się w Pascalach ( $1 \boldsymbol{P a}=1 \mathbf{N} / \boldsymbol{m}^{2}$ ), a ucho ludzkie zaczyna już słyszeć średnio od amplitudy ciśnienia: $\mathrm{p}_{\mathbf{0}}=20 \mu \mathrm{Pa}=2 \cdot 10^{-5} \mathrm{~Pa}$.

Stąd też percepcję dźwięku przyjęto wartościować za pomocą poziomów ciśnienia akustycznego;

$$
\mathbf{L}=20 \log \left(\mathbf{p} / \mathbf{p}_{\mathbf{0}}\right),
$$

gdzie $\mathbf{p}$ jest cienieniem mierzonym w odniesieniu do progu czułości ucha ludzkiego p. 
W gospodarce i technice niezamierzona generacja zjawisk akustycznych przybiera nieraz znaczne poziomy, na granicy bólu dla słuchu (120-130 dBA), lub innego typu szkodliwego oddziaływania, czyli zagrożenia zdrowia czy nawet życia. Przeciwdziałania tym niekorzystnym zjawiskom urosły już do rangi wiedzy i technologii, stąd też niniejsza praca pokazująca to zagrożenie globalnie. Jak bardzo jest ono powszechne w środowisku pracy i życia człowieka pokazuje rozmyta mapka zagrożenia wibroakustycznego środowiska.

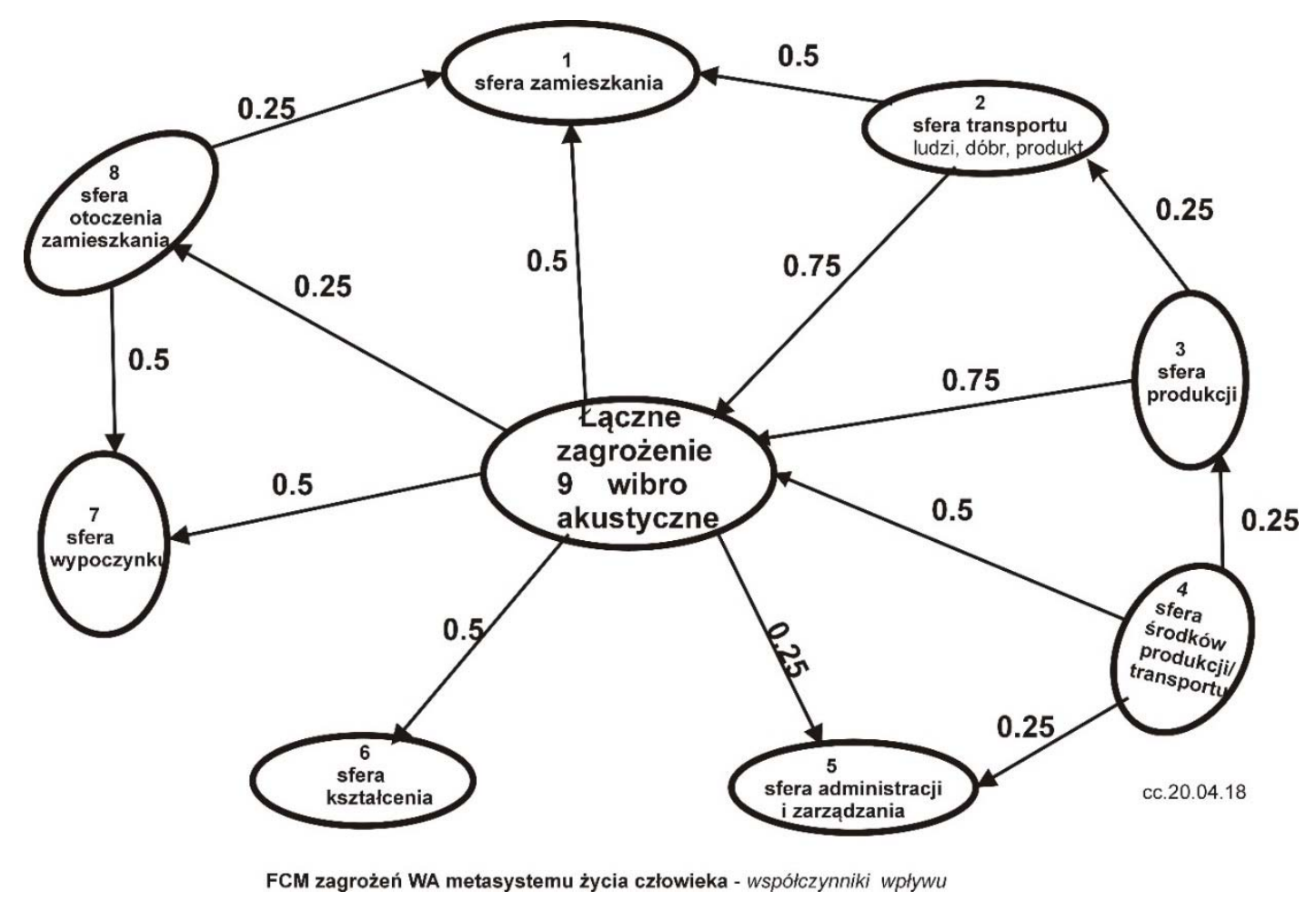

Rys. 1. Rozmyta mapka łącznego zagrożenia WA środowiska człowieka [Cempel 2018]

Rozmyte mapki problemów i systemów wprowadził Kosko [Kosko 1986] i jak widać unormowane $(-1,+1)$ współczynniki wpływu na mapce pokazują nie tylko co jest zagrożone, ale w jakim stopniu i skąd to zagrożenie płynie.

\section{ZRÓWNOWAŻONY ROZWÓJ I ZAGROŻENIA WA}

Wspomniana we wstępie cywilizacja, jaką rozwinęliśmy bazuje na nieodnawialnych zasobach energii i innych potrzebnych nam minerałów i na niezamierzonym niszczeniu 
środowiska. A w drugiej połowie ubiegłego wieku dowiedzieliśmy się z raportów Klubu Rzymskiego [Klub 1972] i innych opracowań, że główne zasoby i samo odnawialność środowiska wyczerpią się za kilkadziesiąt lat, w dostępnym nam horyzoncie czasu. Zatem obecny typ rozwoju gospodarczego został zakwestionowany i obowiązującym paradygmatem stał się rozwój zrównoważony oparty na energiach odnawialnych, recyklingu materiałów i minimalizacji zanieczyszczenia i zagrożenia środowiska, lub szerzej zagrożenia ekosystemu naszego życia i przeżycia.

$\mathrm{Na}$ kanwie tych problemów powstały ekologia, ekoinżynieria i cały szereg fundamentalnych prac i studiów, miedzy innymi; jak rozwój gospodarczy zmienia nam społeczeństwo i środowisko i jak temu przeciwdziałać. Powstały specjalne metody obliczeniowe obciążenia środowiska przez gospodarkę człowieka zwane oceną cyklu życia (Life Cycle Assessment - LCA) dla planowanego lub już produkowanego wyrobu czy procesu w trzech zakresach; szkody w zasobach, szkody w jakości ekosystemu i szkody dla zdrowia $\boldsymbol{i}$ życia czlowieka. Jak się wydaje bardzo dobrze ocenia te szkody specjalna metodologia eko projektowania zwana [Eco-indicator 99]. Mimo że zagrożenia WA mogłyby się tam znaleźć w dwu obszarach liczenia szkód; w obszarze szkody ekosystemu i szkody dla zdrowia i życia człowieka, nie widać tam bezpośrednio uwzględnienia zagrożeń WA. Pewien wyłom w tym myśleniu stanowią prace uwzględniające zagrożenia WA w środowisku poprzez system wskaźników jego jakości, jak np. w pracy [Engel, Zawieska 2011].

W kontekście zagrożeń środowiskowych dużą karierę zrobiła tzw. krzywa Kuznets’a, (odwrócone, $\boldsymbol{U}$ ), która pierwotnie wyjaśniała zmianę nierówności społecznych w funkcji dochodu narodowego $(P K B)$ na głowę mieszkańca [Kuznets 1955]. Bowiem okazało się, że w wielu przypadkach wyjaśnia ona zagrożenie środowiska wraz ze wzrostem gospodarczym, np. zagrożenie dwutlenkiem węgla od rosnącej liczby samochodów itp. Uogólnienie tej krzywej pokazano na rysunku 2 zaczerpniętym z [Budny 2012], zaś strzałki z punktów A i B przestawiają możliwe warianty rozwoju. Jak się wydaje krzywa ta może również odzwierciedlać wibroakustyczne zagrożenie środowiska, gdyż w początkowym etapie rozwoju gospodarczego celem samym w sobie jest rozwój, a dopiero później przychodzi troska o jakość życia i jakość środowiska, w tym też jakość WA. 


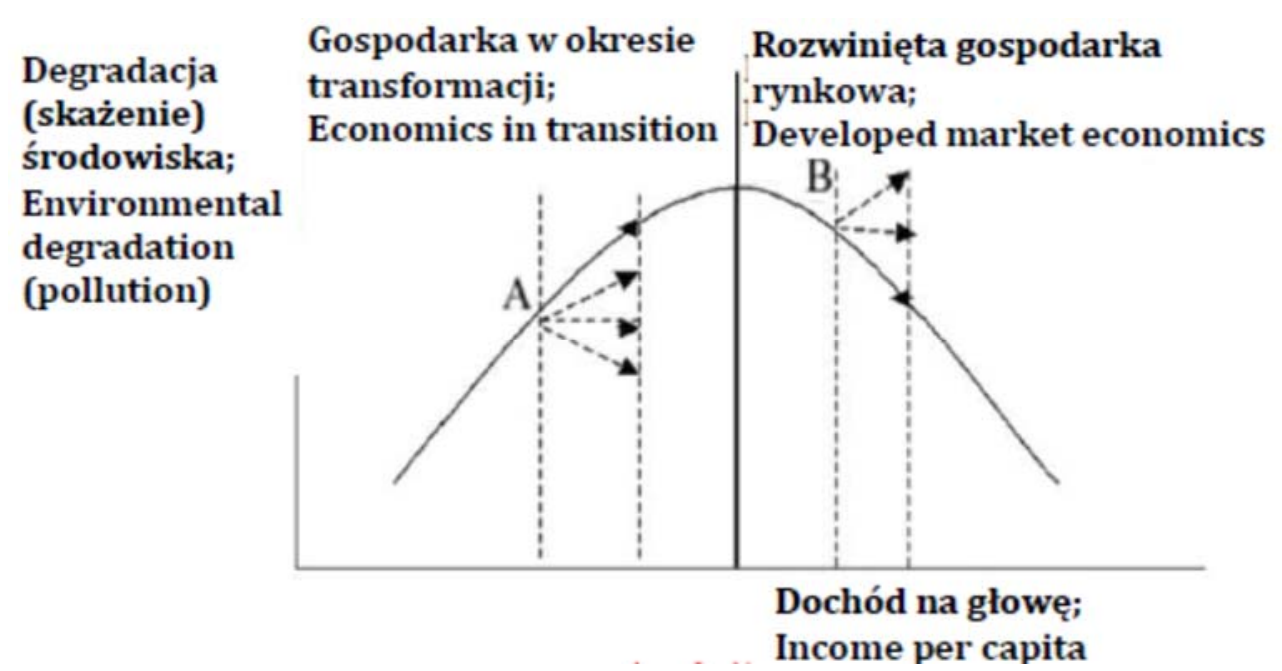

Rys. 2. Uogólniona krzywa Kuznets'a w zastosowaniu do zagrożeń środowiska, [Budny 2012]

Potwierdzeniem tego wydaje się statystyka zagrożenia hałasowego w Europie, która mówi, że w krajach bardziej rozwiniętych EU procent pracowników narażonych na hałas w 2010r wynosi 29\%, jest mniejszy niż np. w Polsce ( 37\%), a pięć lat wcześniej było jeszcze więcej 42\%, [Augustyńska i inni 2012], a my jesteśmy na pewno na wznoszącym się łuku krzywej U rysunku 2.

Zagrożenie WA to nie tylko środowisko pracy, ale też środowisko naturalne jako obszar bytowania roślin i zwierząt i należy liczyć się również z negatywnym wpływem obciążenia hałasowego a nawet WA. Jest trochę badań na ten temat, są już doniesienia, że niektóre ptaki opuszczają miejsca o dużym poziomie hałasu, a ptaki śpiewające w mieście zmieniają brzmienie swego śpiewu, [Slabbekoorn 2006]. Co do wpływu zagrożeń WA na rośliny nie widać jeszcze takich prac, ale wpływ ten z pewnością istnieje.

\section{SYSTEMOWE UJĘCIE ZAGROŻEŃ WA}

Pierwsze myślenie o redukcji hałasu i innych zagrożeń WA w kraju zaczęło się we wczesnych latach 70tych, kiedy to upojenie zbudowaniem pierwszych zakładów przemysłowych zwolna mijało, a w zakładach pracy zaczęły nabrzmiewać problemy bezpieczeństwa pracy, w tym wysokie zagrożenie hałasowe i drganiowe $(\boldsymbol{W} \boldsymbol{A})$ pracowników. Zaczęto znajdywać rozwiązania dla poszczególnych przypadków, ale jednocześnie pojawiły się próby systemowego widzenia zagrożeń WA. Przykładem takiego wczesnego myślenia jest następny rysunek 3, zaczerpnięty z pierwszego wydania książki jednego z autorów z 1978 r. 
Widać tu już system; źródto hałasu i drgań w postaci maszyny (hałas drogowy jeszcze nam wtedy nie dokuczat), droga propagacji jako drugi podsystem i czlowiek operator jako odbiorca tych zagrożeń WA. Poszczególne podsystemy zawierają znane wówczas rozwiązania minimalizacyjne zagrożeń WA i w porównaniu do obecnego stanu wiedzy i techniki brakuje tylko czynnych metod redukcji drgań i hałasu. Brakuje również środków transportu jako źródeł hałasu oraz elektrowni wiatrowych, których jeszcze wtedy u nas nie było.

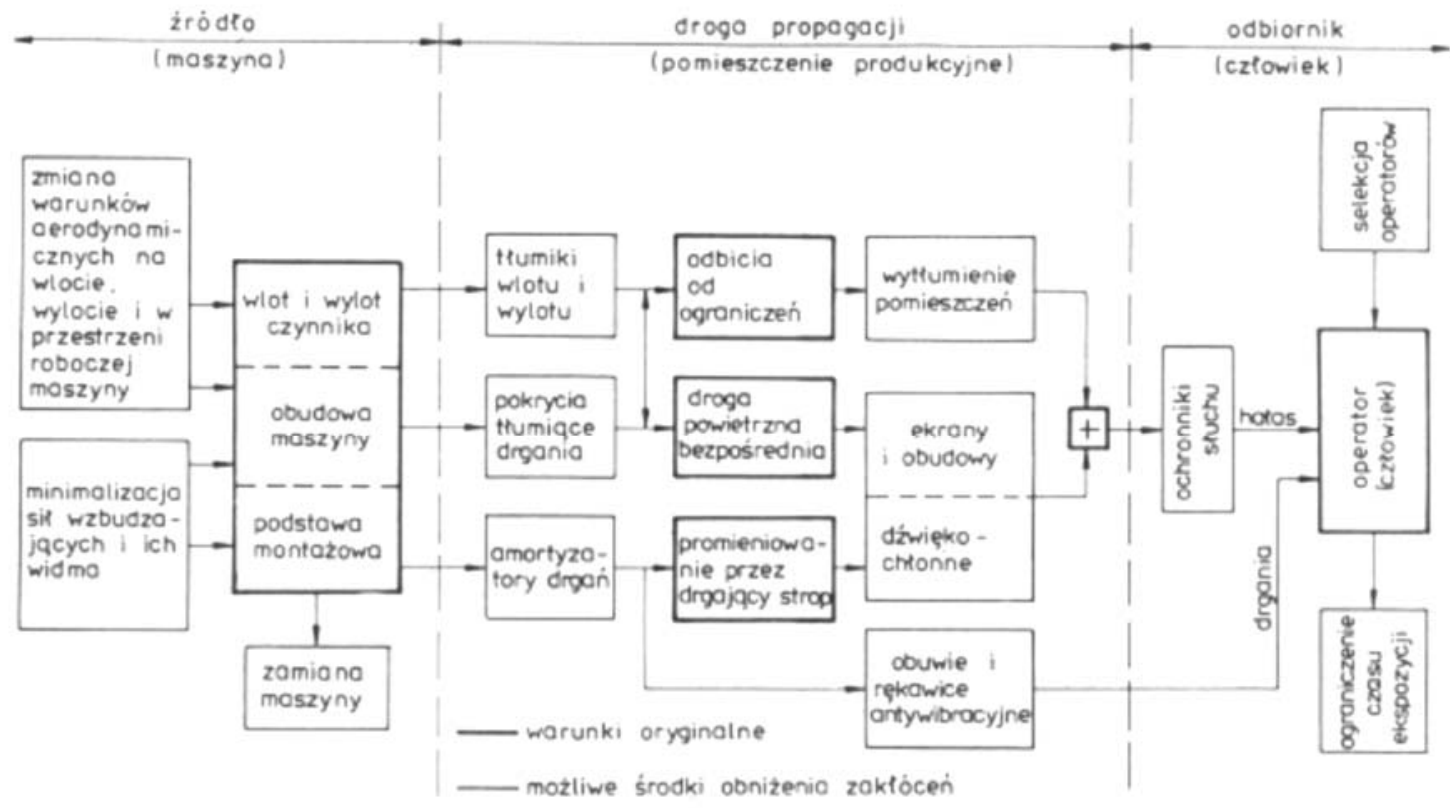

Rys. 3. Wczesne myślenie o systemowym ujęciu zagrożeń WA w przemyśle,[Cempel 1978]

Metody te i dodatkowe źródła hałasu wymieniono bardziej szeroko na mapce myślowej problemu zamieszczonej na kolejnym rysunku 4, (gałęzie 3,4,5 mapki), bowiem z uwagi na przeglądowość pracy nie będziemy ich szczegółowo omawiać. Mapka myśli jest generalnie dobrym narzędziem do myślenia twórczego i warto ją stosować razem z innymi bardziej rozbudowanymi narzędziami kreatywnego myślenia [Cempel 2013], np. dla redukcji hałasu i drgań w otaczającym nas środowisku. 


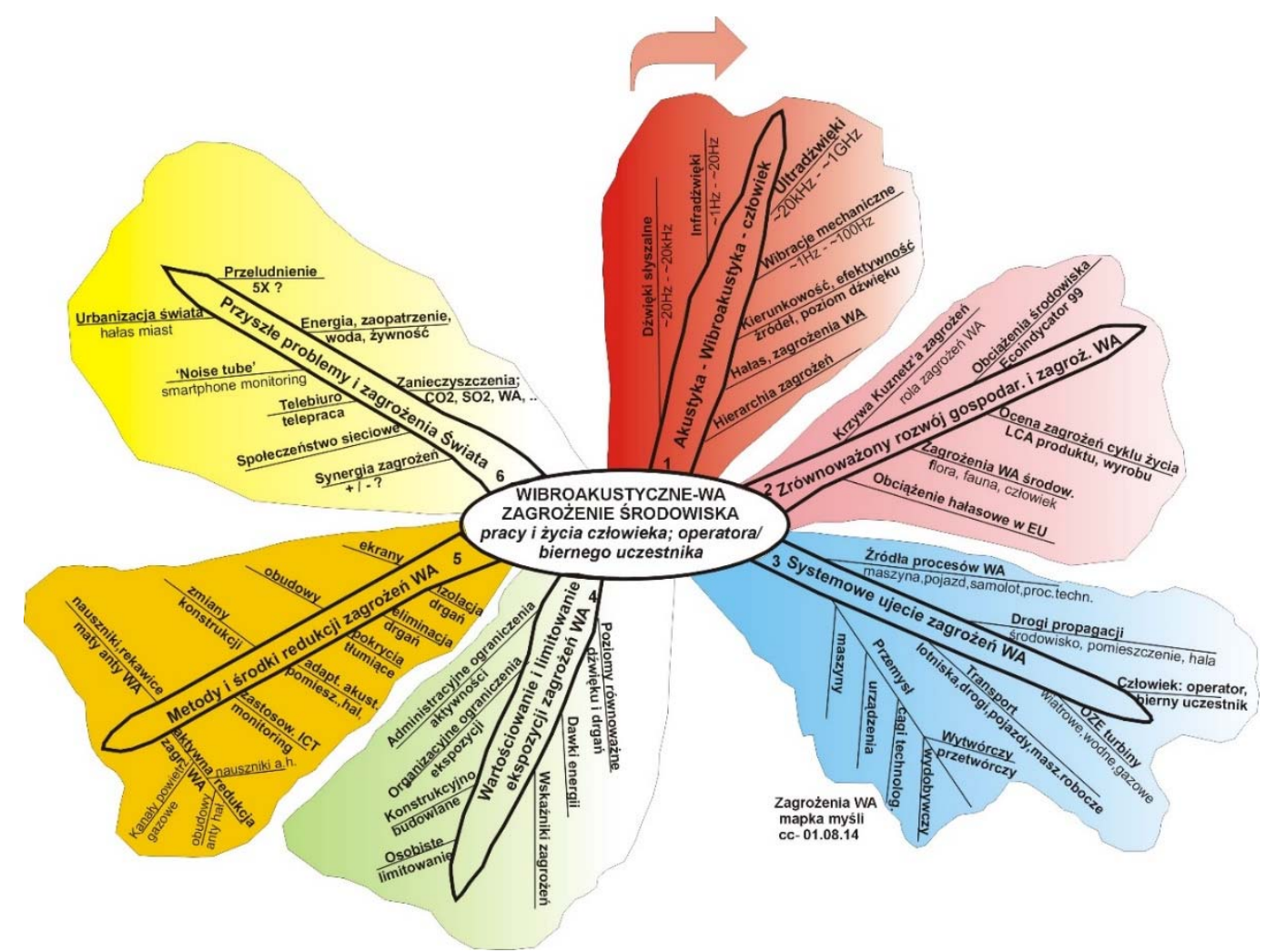

Rys. 4. Mapka myślowa problemu zagrożenia WA środowiska pracy i życia człowieka operatora $\mathrm{w}$ procesie pracy i biernego uczestnika w innych niechcianych zagrożeniach, (np. transportowych).

\section{WARTOŚCIOWANIE I LIMITOWANIE EKSPOZYCJI NA ZAGROŻENIA WA}

Zanim przejdziemy do redukcji hałasu i drgań, musimy upewnić się, że trzeba redukować te zjawiska, a więc powiedzieć coś o ich wartościowaniu i o normach krajowych i międzynarodowych. Generalnie wartościowanie hałasu oparte jest o tak zwaną krzywą A słyszenia dźwięku przez uśrednione ucho, mówimy wtedy o poziomie hałasu w decybelach $\mathbf{A}$ $(\boldsymbol{d} \boldsymbol{B} \boldsymbol{A})$. Jak wiemy z obserwacji, poziom hałasu rzadko kiedy jest stały w czasie, dlatego tez do celów normowania hałasu na stanowiskach pracy jak i w środowisku definiuje się tak zwany poziom ekwiwalentny $\mathbf{L}_{\text {Aeq, }}$ równoważny, przez operację uśrednienia co można wyrazić matematycznie przez operacje całkowania lub lepiej sumowania, jak w poniższym wzorze;

$$
L_{A e q}=10 \lg \frac{1}{T} \int_{0}^{T} \frac{p_{A}^{2}(t)}{p_{0}^{2}} d t=10 \lg \frac{1}{T} \sum_{1}^{N} \Delta t_{i} \cdot 10^{L_{A i}}
$$

gdzie; T jest czasem obserwacji (ekspozycji) hałasu (na ogót 8h), rozbitym na $\mathrm{N}$ odcinków w których poziom hałasu był względnie stały i wynosił $\mathbf{L}_{\mathrm{Ai}}, \boldsymbol{i}=\mathbf{1}, \ldots . . \mathrm{N}$. 
Tak określony poziom równoważny hałasu jest przedmiotem wielu ustaleń normowych krajowych i międzynarodowych (EN, ISO), zarówno na stanowiskach pracy jak i w środowisku w porze nocnej i w dzień. Podstawowa dopuszczalna wartość poziomu to 85dBA, do której dodajemy lub odejmujemy poprawki zależne od typu źródła hałasu, rodzaju stanowiska pracy, itp. [Engel 2001]. Nie będziemy ich tu przytaczać, można je znaleźć w stosownych rozporządzeniach ministerstw i innych organów równorzędnych.

Patrząc ogólnie na poziom równoważny (2) można powiedzieć, że przedstawia on również uśrednioną moc, z jaką proces dźwiękowy działa na obiekt lub operatora. Jeśli taka moc będzie działać w okresie czasu $\mathbf{T}_{\mathbf{D}}$ na obiekt to wykona na nim pracę lub dostarczy mu dawkę energii akustycznej. W niektórych krajach, (np. w USA) przedmiotem normowania jest właśnie dawka hałasu, zaś u nas normuje się w ten sposób maksymalną dawkę drgań mechanicznych, jaką operator może przejąć na stanowisku pracy.

Możemy wreszcie przejść do lewej strony gałęzi 4 i całej gałęzi 5 mapki traktujących o metodach i środkach redukcji zagrożeń WA na stanowisku pracy jak i w środowisku bytowania człowieka i innych jego zagrożonych lokatorów. Oczywiście wpierw, jeśli nie ma innych metod, możemy administracyjnie limitować możliwą ekspozycję na zagrożenia WA stwarzane przez przemysł lub transport. Ale jak widać z gałęzi 5 mapki istnieją środki i metody w inżynierii mechanicznej i budowlanej, które w wielu przypadkach pozwalają skutecznie ograniczyć zagrożenie WA. A ostatnio jako konkurencyjne zjawiają się czynne środki redukcji polegające na redukcji aktywnej (podobnego-podobnym), to znaczy hałas odpowiednio wygenerowanym dźwiękiem, podobnie jak drgania, odpowiednio wygenerowanymi drganiami.

W chwili obecnej można powiedzieć, że większość zagrożeń WA w środowisku pracy i życia człowieka da się sprowadzić do poziomów tolerowalnych. Wpierw jednak trzeba sobie zdać sprawę z istnienia zagrożenia, a potem zatroszczyć się o niezbędna wiedzę i środki dla skutecznej redukcji zagrożenia WA. Można również przypuszczać, że wznoszenie się kraju na krzywej rozwoju gospodarczego (rys.2) doprowadzi nas do drugiego odcinka krzywej Kuznetz'a i jakość WA środowiska ulegnie znacznej poprawie. Trzeba jednak na to samemu zapracować, ale czy tylko, co nam niesie przyszłość w szerszym kontekście życia na Ziemi.

\section{PRZYSZZE PROBLEMY I ZAGROŻENIA NASZEGO ŚWIATA}

Patrząc na naszą przyszłość w szerszym kontekście, to widzimy więcej zagrożeń nie tylko zagrożenia WA, ale także w tym nurcie środowiskowym mamy; $\mathbf{C O}_{2}, \mathbf{S O}_{\mathbf{2}}$ i inne chemiczne 
zagrożenia czystości naszej wody i atmosfery. O braku energii w postaci takiej, jaką wykorzystujemy (ropa) wszyscy słyszeli, bo nawet współcześnie prowadzone wojny mają ją w swym podtekście. Najważniejsze zagrożenie jednak, jak nazwano w raporcie małżeństwa Meadows [Meadows 1972], to bomba demograficzna. Zależnie od sposobu liczenia należnego poziomu życia każdemu na świecie (energochłonność) jest nas co najmniej piec razy za dużo (lub więcej) i w związku z tym w perspektywie pokolenia pojawią się w krajach biedniejszych braki energii, żywności i wody pitnej [Wydolność 2007]. W krajach bogatych, a ten status międzypaństwowej nierówności życia jeszcze się trochę utrzyma, narastać będzie urbanizacja ze wszystkimi skutkami tego zjawiska, co da potrzebę lepszego monitorowania zagrożeń WA w miastach, np. za pomocą sieci i smartfonów [Maiisonneuve 2009]. Informatyzacja społeczeństwa da też pozytywne skutki, organizacyjne, telepraca, telebiuro, co zmniejszy konieczność używania rożnych środków transportu i zmniejszy obciążenie hałasowe środowiska. Światli ludzie mają też nadzieję, że społeczeństwo sieciowe będzie lepiej poinformowane i bardziej współ uczestniczące w rozwiązywaniu swych problemów. Jednak słychać również głosy, że zwiększy to podatność i łatwość prania mózgu na niespotykaną dotąd skalę. Można również spekulować czy synergia wymienionych zagrożeń będzie wzmacniająca czy też osłabiająca, oby to ostatnie.

\section{PODSUMOWANIE}

Praca przedstawia w skrótowej formie współczesne myślenie o zagrożeniach WA w środowisku pracy i życia człowieka. Bowiem, cywilizacja, jaką wytworzyliśmy jest halasotwórcza i hałas wdziera się wszystkimi drogami do naszej pracy i życia. Na szczęście wiele już wiadomo jak minimalizować te zagrożenia WA, trzeba mieć tylko odpowiednią wiedzę i środki. A do tego cywilizacja, jaką tworzymy jest źródłem innych poważnych zagrożeń dla nas samych. Warto więc o tym pomyśleć, by nasze myślenie i działanie było przyjazne środowisku i nam samym. 


\section{Literatura}

[1] Cempel C., Teoria i Inżynieria Systemów, Wyd. ITE Radom, 2008, s. 291.

[2] Engel Z., Ochrona środowiska przed drganiami i hałasem, PWN Warszawa, 2001 wyd. II, s. 490.

[3] Engel Z., i inni, Podstawy Wibroakustyki Przemysłowej, Wyd. AGH, 2003, s. 350.

[4] Cempel C., Wibroakustyka Stosowana, PWN Warszawa, 1978wyd.Isze, 1989, wyd. II, s. 278; patrz też Internet; http://neur.am.put.poznan.pl

[5] Meadows D.H., i inni, Limits to Growth, Klub Rzymski, 1972, p. 338.

[6] Kuznets S., Economic growth and income inequality, The American Economic Review, Vol. 1, (1), No 45, pp. 1-28.

[7] Turowski J., Oszczędzanie czy poszanowanie energii, ekologiczne, socjologiczne i etyczne aspekty gospodarki energią, Inżynieria Przetwórstwa Spożywczego, 2012, No 4, s. 5-11.

[8] Eco-indicator 99 Manuals, http://www.pre-sustainability.com/eco-indicator-99-manuals.

[9] Engel Z., Zawieska M., Noise control at work place as an element of sustainable development, International Congress of Sound and Vibration, Rio de Jeneiro, July 2011.

[10] Hałas a środowisko, Internet; http://www.eko.org.pl/kropla/31/halas.html

[11] Augustyńska D., Pleban D., Radosz J., Zagrożenia hałasem na stanowiskach pracy w Polsce i innych państwach Unii Europejskiej, Medycyna Pracy, 2012, No 63 (6), s. $689-700$.

[12] Slabbekoorn H., den Boer-Visser A., Cities Change the Songs of Birds, Current Biology, Volume 16, Issue 23, 5 December 2006, pp. 2326-2331.

[13] Cempel C., Inżynieria Kreatywności w Projektowaniu Innowacji, Wyd. ITE Radom, 2013, s. 340.

[14] Cempel C., Wydolność geobiosfery i tragedia wspólnot, Transformacje, 2005, 41, No 3-4, s. 133-138; Internet: http://neur.am.put.poznan.pl

[15] Maisonneuve et al, Citizen noise pollution monitoring, The Proceedings of the10th Digital Government Research Conference, 2009, pp. 96-102.

[16] Cempel C., Poszerzanie oglądu i rozumienia nauki, technologii, innowacji, CIOP-PIB, Warszawa 2018, s. 201.

[17] Kosko B., Fuzzy cognitive maps, Int. Journal of Man Machine Studies, 24, 1986, pp. 65-75. 